\title{
A Hyperreality Study on the Game Pamali: The White Lady (2018)
}

\author{
Dessy Dwi Annisa Setyawati*,Trie Hartiti Retnowati, Warid Moga Nugraha \\ Faculty of Languages and Arts, Yogyakarta State University, Yogyakarta, Indonesia \\ *Corresponding Author. Email: dessydwiannisa@gmail.com
}

\begin{abstract}
Due to the current development of technology, video game can actively construct imaginative ideas beyond reality through impressions of signs and images. The media digitalization process supports the simulation process directed toward forms of hyperreality for game aficionados, including the game Pamali: The White Lady (2018), which is a horror simulation game which combines myths and taboos (pamali) in Indonesia. The game is centered around the main character Jaka who experiences various mythical experiences and meets supernatural creatures, including his dead sister who has turned into the ghost kuntilanak when he visits his childhood home to sell it. The combination between myths, taboos, and video game becomes very interesting to study. The current research employs the cultural study method using Jean Bauldrillard's hyperreality theory. The sign analysis in the game Pamali: The White Lady (2018) challenges the boundaries between reality and nonreality through the Unreal Engine 4 advanced technology, which allows the user to manipulate space, time, and character in the game. The game presents reality in the form of supernatural experience by allowing the user to see and feel the presence of the spirits, which most people may not have access to in reality. Through this game, anyone can experience the horror as real as possible in the hyperreality world. Ultimately, reality in the game multiplies and becomes layered (simulacrum) in the sign manifestations that are increasingly blurry, making it difficult to distinguish the imaginary world and the real world.
\end{abstract}

Keywords: Hyperreality, Bauldrillard, Game Pamali

\section{INTRODUCTION}

The rapid development of technology today has resulted in various uses of the latest technology by a great number of emerging industries. Digital technology, for instance, has been utilized in the film, advertising, and game industry with great progress. Recently, in Indonesia, there has been a surging interest in video games across various social levels. Games have the ability to bring the users or players into a virtual world which opens the spatial boundaries between imagination, illusion, and reality. Games may also create and produce impressions of the "second reality" on fantasy through various manifestations of signs, icons, and symbols.

Along with the development of technology, the boundary between reality and fantasy has become blurry. The recent technological advancement has managed to create visual impressions or images. Image, in this context, serves as one of the elements which form culture. The world of image, particularly the visual one, involves the see-be seen activity and sight. This impression involves various capacities of sights and perceptions in accepting and understanding the image [1]. Current technology is capable of creating virtual reality through video or online games. The virtual reality is created through constant and repeated visual imaging which makes the users feel that the boundary between reality and fantasy has become blurry. Innovation in digital technology allows replications of forms that are near-identical to reality. This can be seen in how the Unreal Engine 4 technology from Epic Game is used to create a video game. The game developer uses the engine to create a map, characters, and various additions to the game. The technology serves as a medium of creating simulations of imagination through visual creativity that is capable of generating certain images that may not be possible in the reality. One of the games created using Unreal Engine 4 is called Pamali: The White Lady (2018).

\section{LITERATURE REVIEW}

Pamali is an Indonesian folklore game that is packaged in a game with 1990's Indonesia atmosphere. Pamali: The White Lady (2018) is a horror simulation game which offers a horror experience in a cause-andeffect scheme for the players. The game combines 
Javanese folklores or myths on the kuntilanak ghost and digital technology in a virtual reality. In Indonesian, the word pamali means "taboo". Substantially, the term can be understood as something that must be avoided by the members of community, as there will be consequences for those who violate it [2].

The myth itself in traditional society refers to stories or fairy tales that are believed to be true and become a reference for systems and norms in that society. Myth tells of everything that is beyond human reason. Myths are in the form of oral stories in society. According to Robert A. Segal in the book Myth there is a difference between myths of the nineteenth and twentieth centuries. Myth theory in the nineteenth century is more likely to view nature as the subject of myth and the function of myth, either as a literal explanation or a symbolic description of the world [3]. The myth of the century made nature as its subject. Myth is a language; for a myth to be known, it must be told because it is part of human speech [4]. Although myth is human speech, it can take other forms such as visuals, architecture, objects, sports, fashion, and so on. This is because all mythical material presupposes an awareness of the marker itself. Myth is a story that explains some aspects of reality or explains some aspects of culture. The most important thing in myth is not about right or wrong, logical or illogical, but about whether or not it is believed [1]. The myths of the past, which have only been disseminated through speech, are now about to be revisited and repackaged in a video game which can certainly remind both the young and old generations about the myths that exist in their area.

The advanced development of technology has managed to create a world of "reality". The game Pamali: The White Lady (2018) offers a reality that is represented or simulated in a medium of technology. The game combines myth and technology and presents a form of hyperreality to the players or the viewers of gaming content on Youtube channels. The concept of hyperreality was popularized by a French thinker named Baudrillard. This idea is related to the concepts of simulation, simulacra, and simulacrum which explain the conditions of virtual and artificial reality in the present era. A person who is exposed to the media experiences manipulation which is formed through simulation or imitation of images and symbols, which then makes up the fake or false reality. This false reality is manifested by performing simulations continuously in time and space. An object can represent reality through its signifier, which has a certain meaning or signified. In this case, reality is the reference of the marker. However, it could also be that an object does not refer to a particular reference or reality at all, because it itself is a fantasy, imagination or hallucination that has become reality [5]. According to Baudrillard, the era of hyperreality is marked by the disappearance of markers and metaphysics of representation; the collapse of ideology, and the bankruptcy of reality itself which is taken over by duplication of the world of nostalgia and fantasy or becoming a substitute reality for reality. The fetish of the missing object is no longer an object of representation, but the ecstasy of denial and its own ritual annihilation [6].

In the daily activities of society, reality is formed through media that are educational, informative, and entertaining in certain areas. The media actively builds reality and presents it with simulations that encourage imaginative ideas among people so that they "lead" into consciousness in a multiple simulation process. The combination of several simulations is then called simulacra. Video games produce imagination to the audience, and the condition in which the image is considered more important than the "real" world. People continue to be brought into the world of imagination to the point that they experience difficulties distinguishing between pseudo-reality and the actual reality because they have merged into one [7]. Reality can now be displayed in representations and simulations. Representation is a sign that is displayed with a reference in the real world. Meanwhile, simulation can occur when a sign or marker does not refer to a particular reference or reality. This happens because the marker is an imagination that does not refer to the reality that exists in the real world.

There are three levels when discussing reality and representation. The first is presentation, that is when reality is presented to us without any technological mediation. The second one is representation, which is when reality cannot be presented, and mediation is used to present the reality through technological media. Lastly, simulation is when facts are presented through a 'model' without any reference to a reality. Simulation comes with showing reality without any reference in our real world. It only refers to itself. This condition is called hyperreality [1].

In the world of hyperreality one can distinguish between real, factual, and virtual. Real is something that exists in the real world. Factual is what is in a phenomenon, whereas virtual means that it only exists in the world of technology without existing in the real world. [1]. Through the means of technology and science, the world of hyperreality can create artificial realities that offer various kinds of new experiences, sceneries, and explorations that may have been out of reach before. Various forms of myths, fairy tales, imagination, hallucinations and fantasies were not considered part of reality. However, with the development of the technological world, these things can be realized into a reality. It is in this condition that the boundary between reality and non-reality becomes blurred and sometimes overlaps. As is the case in the game discussed in this study, myth, that used to be considered as a non-reality, is now elevated and reintroduced as a horror game.

Pamali: The White Lady (2018) is an indie game by the StoryTale studio that is based in Bandung, West 
Java. The game was first released on December 28, 2018. There are four storylines in the game; each is based on the ghost character. The first one is about the kuntilanak ghost (the white lady), the second one is the pocong ghost (the tied corpse), the third one is the tuyul ghost (the little devil), and the last one is the leak (the hungry witch). The StoryTale Studio aims to introduce Indonesian myths to the world, however the game is limited to only three storylines. This study, more specifically, focuses only on the myth of the kuntilanak ghost (the white lady). In summary, the game Pamali: The White Lady (2018) follows a journalist named Jaka who wishes to sell his childhood house in West Java. The player of the game will take the role of Jaka. The game is based on the Javanese myth in which the ghost will appear if the pamali or taboo is violated. The hooror game is a single-player game with a click-andplay system. At the moment, the game is available on Steam and can only be played on PC (Personal Computer). The plot reflects a form of hyperreality in a horror game through impressions and images produced into the game medium. This study aims to address the following question: "How is the form of hyperreality presented in the game Pamali: The White Lady (2018)?". The answer to the question is important as a form of critical reflection on the human awareness in viewing a video game, not merely as a medium of entertainment, but also as one that plays an active role in constructing reality. The objective of this study is to see the hyperreality which exists in the game Pamali: The White Lady (2018).

\section{RESEARCH METHOD}

This study is based on a qualitative research with cultural study focusing on the reflection methodology to achieve critical awareness. The study employed semiotic approach as the means for reading the signs in the game in the audiovisual context. Next, Baudrillard's theory was applied to examine the hyperreality in the game Pamali: The White Lady (2018). Baudrillard's notion of hyperreality places simulacra as an important part in the analysis project that is divided into several phases, namely the image that will be the manifestation of a reality, the image that shifts and will be distorted from reality, the image that will replace reality, and lastly, the image which no longer has a reference from any reality, which is known as hyperreality [8]. Data were obtained from observations and grouped into primary and secondary data. The primary data consisted of several pamali scenes done by Jaka in the game Pamali: The White Lady (2018), whereas the secondary data included relevant references and internet sites. Visual data were obtained by the screenshot of the scenes in the game indicating hyperreality traits.

\section{DISCUSSION}

In the game Pamali: The White Lady (2018), the player plays the character of an indie game developer who is having trouble coming up with ideas on a horrorthemed game. The character emails his friends asking for horror experiences or stories, which will serve as the basis of developing the game. In addition, a big board called the "Jurig Board" is prepared to put together horror stories from the research. In Sundanese, jurig means "ghost". The first email is from Rika, who tells the story of her friend, Jaka. At this point, the character is asked to investigate and imagine the cause-and-effect scenario that might happen to Jaka by playing the game Pamali: The White Lady (2018).

The story begins in the 1980's. There once lived a family who lived in peace in West Java. The family was Jaka, Nenden, and their parents. Nenden was Jaka's older sister who got married to a soldier and lived in her parents' house. Despite several years of marriage, Nenden still had no child. Fast forward to the 1990's, Jaka went to Jakarta to pursue his dream to be a journalist. Nende's husband went away for his army duty, leaving Nenden alone as Jaka decided to leave for school. After a few years, Nenden got pregnant and gave birth to her only child, while Jaka graduated and got a job as a journalist in Jakarta. Jaka's busy work made it difficult for him to go back home and see his family. Nenden's child died at birth and she got depressed. Her husband helped her get through the difficult time, but to no avail, as she died a few days later. The family was left shocked, yet Jaka was not able to return home due to work. Time passed, and Jaka's parents were the only ones who lived in the house. For more than one year, they had been haunted by Nenden's spirit which loomed about the house due her great sadness and loss. Because of this, Jaka's parents used various measures to get rid of the spirit, such as putting sharp objects believed to dispel spirits around the house such as nails, scissors, and cutters, and hiring a paranormal expert. Their efforts worked, and Nenden no longer haunted the house. As Jaka got busier and unable to go home, Jaka's parents decided to visit Jaka in Jakarta. However, on the way, they got into a car accident, and Jaka not only lost his sister, but also his parents. Jaka thought it was Nenden's spirit which caused the accident as she was expelled from the house. After a year, the house became vacant and Jaka decided to sell the house. Jaka's house is depicted as a typical 1990's Javanese house with Indonesian furnitures. There is a weeping fig tree in the front yard, which is believed to be the home of supernatural beings. The image of the house can be seen in Figure 1 [11] below. 


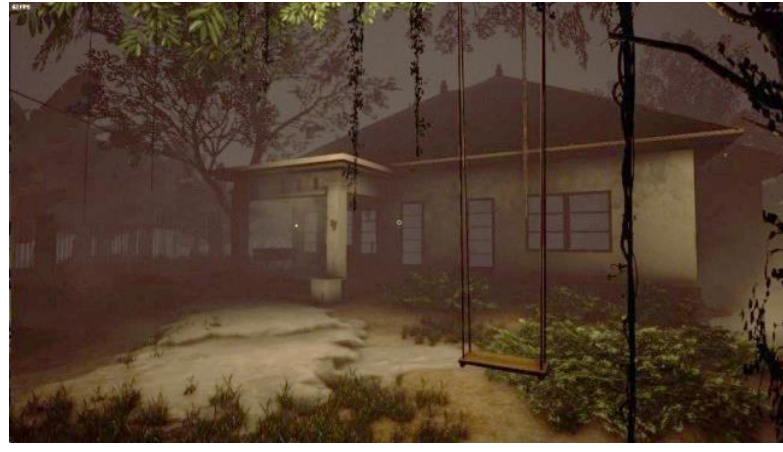

Figure 1. Jaka's house in West Java

Jaka must retrieve important documents and clean the house, but once the house was clean, Nenden's spirit began to gaunt Jaka, creating frightening terrors of myth-related mystical incidences in the house. For instance, there is a myth that throwing away sharp object, according to the Javanese people, is a taboo because sharp objects are believed to rid of spirits such as kuntilanak. When Jaka's parents were alive, they would hide sharp objects such as scissors and nails in the corners of the house. Moreover, the player must avoid sompral, which means "doing disrespectful acts or speech". When encountering an object, the player as Jaka must decide to either keep it or throw it away. The latter option will result in being haunted by kuntilanak Nenden. Each decision the player makes in the game will affect the ending of the story, with a total of 35 different endings to the story.

In the game, the player will face the kuntilanak Nenden figure. Kuntilanak is a ghost that is believed to be once dead pregnant women or women who died at labor with the baby. The ghost is depicted as having very long hair in a white dress. Only those with supernatural powers or an "indigo" person can see this figure. However, with the Unreal Engine 4 game developer technology, this ghost character can be presented as real as it gets in the game medium. The kuntilanak Nenden character in the game can be seen in Figure 2 below [11].

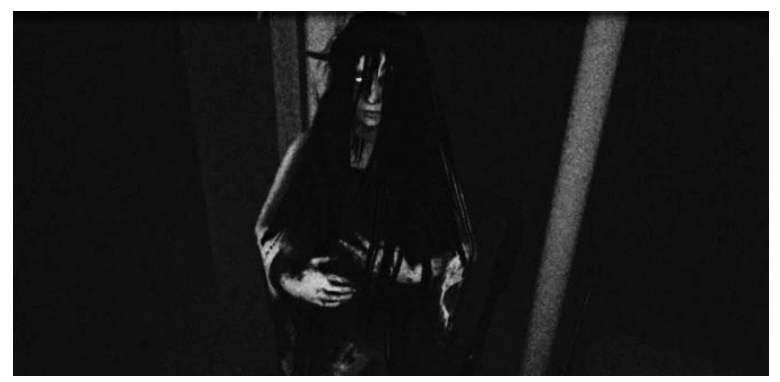

Figure 2. The ghost kuntilanak Nenden

The storyline of the game begins when Jaka is about to enter his house. A moment after the player enters the game, there will be sound heard from the phone call conversation between Jaka and a woman about Jaka's plan to sell his house. It must be noted that the game produced by StoryTale Studio has an English language option for non-Indonesian players. After the phone call, the player has three days to clean the house. Each night, the player will experience sightings at the house. The chilling atmosphere is supported with an appropriate music background. The sound effects in the game were sourced from real-life sounds, such as door opening, an object dropped to the floor, and the lullaby sung by kuntilanak Nenden. When the player enters the ghost's room and plays the radio inside, the song played is "Lingsir Wengi", which is believed by many as a song which calls supernatural beings. The game will allow the players to experience a real-life horror experience sensation. For instance, when the player opts to "mock" the baby doll in Nenden's room, the atmosphere will become unsettling with the sudden lights out and the sound of a woman crying. The character Jaka will not be able to move for a while, and when he is able to, the ghost kuntilanak Nenden will appear sitting down on the chair while carrying a child as seen in Figure 2. Another being which appears in the game is a pocong (shrouded ghost) in the second storyline, which will jump around if the player opts to "mock" the bolster in Nenden's room by completing the narrative "If it could jump, it would look like ...". Then, the player may choose to hide under the bed.

Sightings of kuntilanak may appear due to our disrespectful attitude while playing the game. Several locations of the sightings include at the top of the weeping fig tree, on the rooftop, by the window in the kitchen, flying from the rocking chair, and near the back door. The last one especially has the most nervewracking jump-scare as the ghost kuntilanak Nenden may suddenly move forward and goes through Jaka's body. The horror occurrence that the player experiences could feel more frightening as the ghost kuntilanak Nenden does not necessarily attack, but consistently disrupts and shows herself. The chilling sensation may feel more real as in the real world, ghost sightings do not really have damaging impacts or directly interact with humans.

The horror experience in the game is certainly supported with the sound effects, images, and terrifying atmosphere with the background of an old 1999's house. The game brings us across time and space, as players in the current age can experience mystical horror story experience in the past. Moreover, the gamma setting of the game amplified the horror atmosphere into a more real one. Gamma refers to the screen or display brightness level on the computer. In the game, the gamma level is adjusted to the time of day during which the game is played. For example, during night-time, the gamma will be dimmer, and during the day, the screen will be slightly brighter. The best time to experience the game is during night-time using a headset to intensify the real-life horror experience. Such experience is included in the simulation of Jean Bauldrillad's hyperreality.

Furthermore, regarding the relationship between the simulated world and hyperreality, Bauldrillard argues that pseudo reality that is repeatedly presented will 
make something that is not real into a real thing through the simulation mechanism. This game, as Bauldrillard said, contains simulations that can create "reality". The repetition of this simulation then creates a reality that only exists in the game world. This is part of the world of factual hyperreality, which concerns about what is in a phenomenon. The kuntilanak Nenden character is an example of this, because although it can be categorized as a fact, it is actually not real. The repetition process of this simulation then leads to the simulacra, which is the process of reproducing objects or events [9]. We are faced with a reality which makes us uncertain about what is reality or non-reality. The most prominent thing in hyperreality is that there are new experiences that are offered to humans. Such experiences become the heart of hyperreality [1]. Not everyone can have such experiences in the real world. The development of technology as a medium of manifestation of hyperreality makes it possible to make something that is not real seem real. The fact creates fantasy that is unachievable in reality, yet digital technology allows for the simulation world that is continuously multiplied [10].

Through the game Pamali: The White Lady (2018) which raises the theme of myths and pamali among the Indonesian society, the players or viewers of Youtube gaming channels can observe a small example of hyperreality and are therefore building a critical awareness in seeing the world. Through the game, we can learn about the things we must not do in real world to avoid being haunted by supernatural beings. Not only the game may bring us to the past, we can also experience horror occurrences and learn from wicked things we do when playing the game. The experience in the simulation ultimately helps the players or viewers to be more careful and respectful in the real world to avoid being disturbed by supernatural beings and have good manners in the social life.

\section{CONCLUSION}

Based on the discussion, it can be concluded that the production of images and signs that is carried out continuously can make game players feel like they are entering a world of hyperreality where reality and nonreality feel blurry or overlapping. The process of media digitization allows for repetitions of the simulation process which ultimately creates a form of hyperreality to the players of the game Pamali: The White Lady (2018) or viewers of gaming content on Youtube channels.

Hyperreality in the game is created using a game developer technology called Unreal Engine 4 from Epic Game. The technology makes it possible to manipulate space, time, and characters, and makes the imaginative world look real. The reality element in this game is in the form of folklore about myths and pamali about the kuntilanak ghost which is then manifested in the form of visual images through technology. When the users play the game, they will be subject to horror experiences that not anyone can have in the real world. Ultimately, this repeated experience of playing the game becomes the simulacrum. Through the factual hyperreality that is presented in this game, the character of kuntilanak Nenden in fact only exists in the game world; meaning that the character can be categorized as a fact, but at the same time not real. As a result, there is no distinguishing between the imaginary reality and the actual reality in the real world.

\section{REFERENCES}

[1] Piliang, Y. A., \& Jaelani, J. Teori budaya kontemporer: penjelajahan tanda dan makna [Contemporary cultural theory: the exploration of signs and meanings]. Aurora, 2018.

[2] Achmad, S. W. Pamali \& Mitos Jawa "Ilmu Kuno” Antara Bejo dan Kesialan [Pamali \& Javanese Myths "Ancient Science" Between Fortune and Misfortune]. Araska, 2014.

[3] Segal, R. A. Myth: A very short introduction. OUP Oxford, 2004.

[4] Lévi-Strauss, C. (1967). The structural study of myth. Literary theory: An anthology, $3^{\text {rd }}$ edition, edited by Julie Rivkin \& Michael Ryan, pp. 10118.

[5] Piliang, Yasraf Amir. Sebuah Dunia yang Dilipat [A Folded World]. Mizan, 1998.

[6] Martadi. Hiper-Realitas Visual [Visual Hyperreality]. Nirmana, vol. 5, no. 1, 2003, pp. 80-95. DOI: 10.9744/nirmana.5.1.

[7] Hereyah, Y. Media Massa: Pencipta Industri Budaya Pencerahan Yang Menipu Massa Studi Simulacra Dan Hiperrealitas Film AVATAR [Mass Media: The Creator of the Enlightenment Culture Industry Who Deceived the Mass of Simulacra Studies and the Hyperreality of AVATAR Films]. Ultimacomm: Jurnal Ilmu Komunikasi, vol. 3, no.2, 2011, pp. 95-104. DOI: 10.31937/ultimacomm.v3i2.204

[8] Piliang, Y. A., \& Adlin, A. Hipersemiotika: tafsir cultural studies atas matinya makna [Hypersemiotics: interpretation of cultural studies on the death of meaning]. Jalasutra, 2003.

[9] Kellner, D. Budaya media: cultural studies, identitas, dan politik: antara modern dan postmodern [Media culture: cultural studies, identity, and politics: between modern and postmodern]. Jalasutra, 2010.

[10] Andreas, R. Analisis Hiperrealitas dalam Film Spiderman: Far from Home (2019) [Analysis of Hyperreality in Spiderman: Far from Home (2019)]. Proceeding of The URECOL, 2020, pp. 31-38. URL: shorturl.at/txLMO

[11] Wardhaningsih, M, director. Pamali: Indonesian Folklore Horror. StoryTale Studios, 2010. Author's screenshot. 